\title{
Presence of eaeA sequences in pathogenic and non- pathogenic Escherichia coli strains isolated from weaned rabbits
}

\author{
SABINE M. LEROY, MARIE-CLAUDE LESAGE, ELISABETH CHASLUS-DANCLA* \\ and J. P. LAFONT \\ Station de Pathologie Aviaire et de Parasitologie, Institut National de la Recherche Agronomique, Centre de Tours, \\ 37380 Nouzilly, France
}

\begin{abstract}
Summary. Seventy-one Escherichia coli strains isolated from diarrhoeic weaned rabbits from different areas of France were tested for the presence of DNA sequences specific for the EPEC, EHEC, DAEC and EAggEC strains and 16 of them were tested for pathogenicity in animal experiments. High pathogenicity was observed only with strains unable to ferment rhamnose. DNA from all 55 rhamnose-negative $\mathrm{O} 103, \mathrm{O} 26$ and rough strains hybridised with the eae $A$ probe. Similar hybridisation was obtained with six non-pathogenic rhamnosepositive strains belonging to serogroups $\mathrm{O} 128$ and $\mathrm{O} 132$. No hybridisation was observed with the other probes. This is the first report of the presence of eaeA sequences in genomic DNA of non-pathogenic strains.
\end{abstract}

\section{Introduction}

In industrial rabbit-fattening farms, severe enteric disease is associated with colonisation of the distal ileum and caecum by Escherichia coli strains. Different serogroups of diarrhoeagenic $E$. coli have been isolated from weaned rabbits. ${ }^{1,2}$ These strains produce profuse watery diarrhoea associated with a high mortality. In 1977, a highly pathogenic O15:H - strain, called RDEC-1, was described. ${ }^{3}$ This strain is now considered to be an enteropathogenic $E$. coli analogue and the reference model of $E$. coli diarrhoea in rabbits. In France, the disease is mainly associated with strains belonging to serogroup $\mathrm{O} 103$. These strains adhere to rabbit isolated intestinal villi and to HeLa cells in a diffuse pattern. A $32-\mathrm{kDa}$ protein has been identified as being involved in these attachment mechanisms. ${ }^{4}$ One $\mathrm{O} 103$ strain has been shown to induce characteristic attaching and effacing $(\mathrm{A} / \mathrm{E})$ lesions as seen by electronmicroscopy. ${ }^{5}$ Identical A/E lesions are produced by human enteropathogenic (EPEC) and enterohaemorrhagic (EHEC) $E$. coli strains. ${ }^{6,7} \mathrm{~A}$ chromosomal locus designated eae, ${ }^{8}$ and more recently eae $A,{ }^{9}$ was identified in human EPEC strain E2348/69 and was required for the production of $\mathrm{A} / \mathrm{E}$ lesions in tissue-culture cells. The eae $A$ gene has been detected with a probe containing an internal $1-\mathrm{kb}$ fragment of this gene in all the EPEC strains, in the rabbit pathogenic strain RDEC-1 and in the majority of EHEC strains tested. The eaeA gene is involved in

Received 24 May 1993; accepted 21 June 1993. the intimate attachment stage leading to induction of the A/E lesions. The product of the eae $A$ gene is a 94$\mathrm{kDa}$ outer-membrane protein termed intimin and its expression is enhanced by the presence of the EAF plasmid. ${ }^{10}$

In the present study, the eae $A$ probe was tested on strains of different serogroups, including O103, isolated from weaned diarrhoeic rabbits from different parts of France. All the isolates were also tested with other DNA probes specific for EPEC, EHEC, diffuse adhesion $E$. coli (DAEC) and enteroaggregative $E$. coli (EAggEC). The EAF probe, a DNA segment of a plasmid discovered in most EPEC strains, was used. This plasmid encodes the capacity for the strains to exhibit a localised adherence pattern to HEp- 2 cells ${ }^{11}$ and is required for the full expression of pathogenicity of EPEC strains. ${ }^{12}$ EHEC strains are identified by the presence of structural genes for Shiga-like toxins SLTI and SLTII $^{13}$ and of a plasmid pCVD419-derived fragment that hybridises with most EHEC strains. ${ }^{14}$ DAEC strains can be characterised by a fragment of a chromosomal gene coding for F1845, a fimbrial adhesin mediating diffuse adherence in tissue culture cells. ${ }^{15}$ A DNA fragment of a plasmid conferring an aggregative-adhesion pattern to $\mathrm{HEp}-2$ cells is considered to be specific for EAggEC strains. ${ }^{16}$ All these sequences were used as probes in the present study.

\section{Materials and methods}

\section{Strains}

Seventy-one $E$. coli strains were studied. Their 
Table I. Properties and origins of the 71 E. coli strains studied

\begin{tabular}{lccc}
\hline \multicolumn{1}{c}{$\begin{array}{c}\text { Strain } \\
\text { nos. }\end{array}$} & O serogroup & $\begin{array}{c}\text { Rhamnose } \\
\text { fermentation }\end{array}$ & $\begin{array}{c}\text { Reference } \\
\text { no. }\end{array}$ \\
\hline B10 & 103 & - & 2 \\
C55, C70, D94, D139 & 103 & - & 2 \\
E1, E13, E22, E31 & 103 & - & 2 \\
BN9010-BN9051 & 103 & - & This work \\
C102, C230, D145 & 26 & - & 4 \\
C110 & Rough & - & 4 \\
C124, C127 & 103 & + & 2 \\
C6, C104 & 128 & + & 2 \\
BN9080 & 128 & + & This work \\
BN9081 & 132 & + & This work \\
E40, E70 & 132 & + & 2 \\
B76 & 102 & + & 4 \\
A155 & 85 & + & 2 \\
D28 & 15 & + & 2 \\
C121 & 4 & + & 4 \\
B72, C157, C178, D100 & 2 & + & 2 \\
& & & \\
\hline
\end{tabular}

properties and origins are listed in table I. They were isolated between 1981 and 1990 from weaned diarrhoeic rabbits from different areas of France. They belonged to nine $\mathrm{O}$ serogroups and 53 of them were of the major serogroup $\mathrm{O} 103 ; 51$ strains of this serogroup were unable to ferment rhamnose, a property which correlates well with the expression of pathogenicity. ${ }^{2}$ Most of these strains harboured several plasmids, including one of $c .120 \mathrm{~kb}$.

\section{Experimental pathogenicity}

Animal experiments were performed with 16 bacterial strains. The strains BN9010-BN9019, BN9080 and BN9081 from our laboratory (table I) were tested in experimental conditions as follows: specificpathogen-free New Zealand White rabbits from the Station de Pathologie Aviaire et Parasitologie, INRA, Tours, France, were inoculated at 32 days of age with $10^{7}$ bacteria by stomach tubes. Each strain was tested on eight animals alloted to two cages which were maintained in controlled conditions, avoiding crosscontamination.

Strains from other sources (table I) had been tested already under experimental conditions described previously. ${ }^{2,4,17}$ To compare these animal experiments, strains B10, C6, C124 and E40 were included in the present study.

Diarrhoea and mortality were recorded daily. The animals were weighed three times per week over a period of 17 days. The samples for bacteriological study were taken immediately before inoculation and every 3 days until the twelfth day after inoculation.

\section{$D N A$ probes}

The probes used are listed in table II. DNA probes were prepared from recombinant plasmids containing the probe fragments as inserts. Caesium chloridepurified plasmids from the different recipient strains
Table II. Properties of the probes used

\begin{tabular}{llrlc}
\hline Probe & $\begin{array}{c}\text { Recombinant } \\
\text { plasmid }\end{array}$ & Size (bp) & $\begin{array}{l}\text { Restriction } \\
\text { site }\end{array}$ & $\begin{array}{c}\text { Reference } \\
\text { no. }\end{array}$ \\
\hline eaeA & pCVD434 & 1000 & SalI-KpnI & 8 \\
EAF & pJPN18 & 1000 & BamHI-SalI & 11 \\
SLTI & pJN37-18 & 1142 & BamHI & 13 \\
SLT II & pNN111-19 & 842 & PstI & 13 \\
CVD419 & pCVD419 & 3400 & HindIII & 14 \\
F1845 & pSLM852 & 370 & PstI & 15 \\
EAggEC & pCVD432 & 1000 & EcoRI-PstI & 16 \\
\hline
\end{tabular}

were digested with appropriate restriction endonucleases under the conditions recommended by the manufacturer (Boehringer Mannheim, Germany) and electrophoresed on a low-melting-point agarose $0.8 \%$ gel. Appropriate fragments were cut out of the gel and eluted by an agarase extraction procedure. ${ }^{18}$ Probes were labelled with $\alpha_{-}{ }^{32}$ P-CTP (Amersham International) by a random primed DNA labelling kit (Amersham).

\section{Colony and Southern blot hybridisation}

Bacterial colonies were transferred to several Hybond-N membranes (Amersham), grown for $4 \mathrm{~h}$ at $37^{\circ} \mathrm{C}$, lysed and hybridised at $65^{\circ} \mathrm{C}$ to each labelled DNA probe in $6 \times \mathrm{SSC}(1 \times \mathrm{SSC}: 0 \cdot 15 \mathrm{M} \mathrm{NaCl}, 0 \cdot 015 \mathrm{M}$ sodium citrate), $5 \times$ Denhart's solution $(1 \times$ Denhart's: polyvinylpyrrolidone $0.02 \%$, Ficoll $0.02 \%$, bovine serum albumin $0.02 \%$ ), SDS $0.5 \%$, denatured herring sperm DNA $250 \mu \mathrm{g} / \mathrm{ml}$. Colony blots were washed successively at $65^{\circ} \mathrm{C}$ in $2 \times \mathrm{SSC}$, SDS $0.1 \%$ and in $0 \cdot 1 \times$ SSC. The filters were autoradiographed for $5 \mathrm{~h}-2$ days at $-80^{\circ} \mathrm{C}$ with intensifying screens.

Plasmid DNA was prepared as described by Takahashi and Nagano. ${ }^{19}$ Total DNA was purified by the method of Wilson ${ }^{20}$ with some modifications: bacterial cells were lysed with SDS; proteins and cellular debris were removed by digestion with proteinase $\mathbf{K}$ and precipitation with hexadecyltrimethyl ammonium bromide. DNA was obtained after two extractions with phenol-chloroform-isoamyl alcohol and precipitation with isopropanol. DNA samples were digested with $H$ indIII and Pst I according to the manufacturer's instructions (Boehringer). Plasmids or total DNA fragments were separated by electrophoresis on an agarose $0.8 \%$ gel, transferred to a nylon membrane and incubated with the radiolabelled $e a e A$ probe as described for colony blot hybridisation.

\section{Results}

\section{Experimental pathogenicity}

Strains BN9010-BN9019 were highly pathogenic for rabbits, with a mortality rate of $50-90 \%$ from day 4 to 12 . Before death, all animals exhibited depressed growth and diarrhoea, generally of haemorrhagic type. 




Fig. 1. Analysis of DNA by colony hybridisation. Total DNA was transferred to a nylon membrane and hybridised to the ${ }^{32} \mathrm{P}$-radiolabelled eae $A$ probe. 1 and 59, HB101 as negative control; 2 and 60, E2348/69 as positive control; 3-6, B72, C157, C178, D100; 7, A155;8-10, C102, C230, D145; 11, D28; 12, B10; 13-47, BN9010-BN9044; 48 and 49, C124, Cl27; 50, C55; 51-53, C6, C104, BN9080; 54-56, E40, E70, BN9081; 57, C110; 58, B76. Other strains from table I, data not shown.

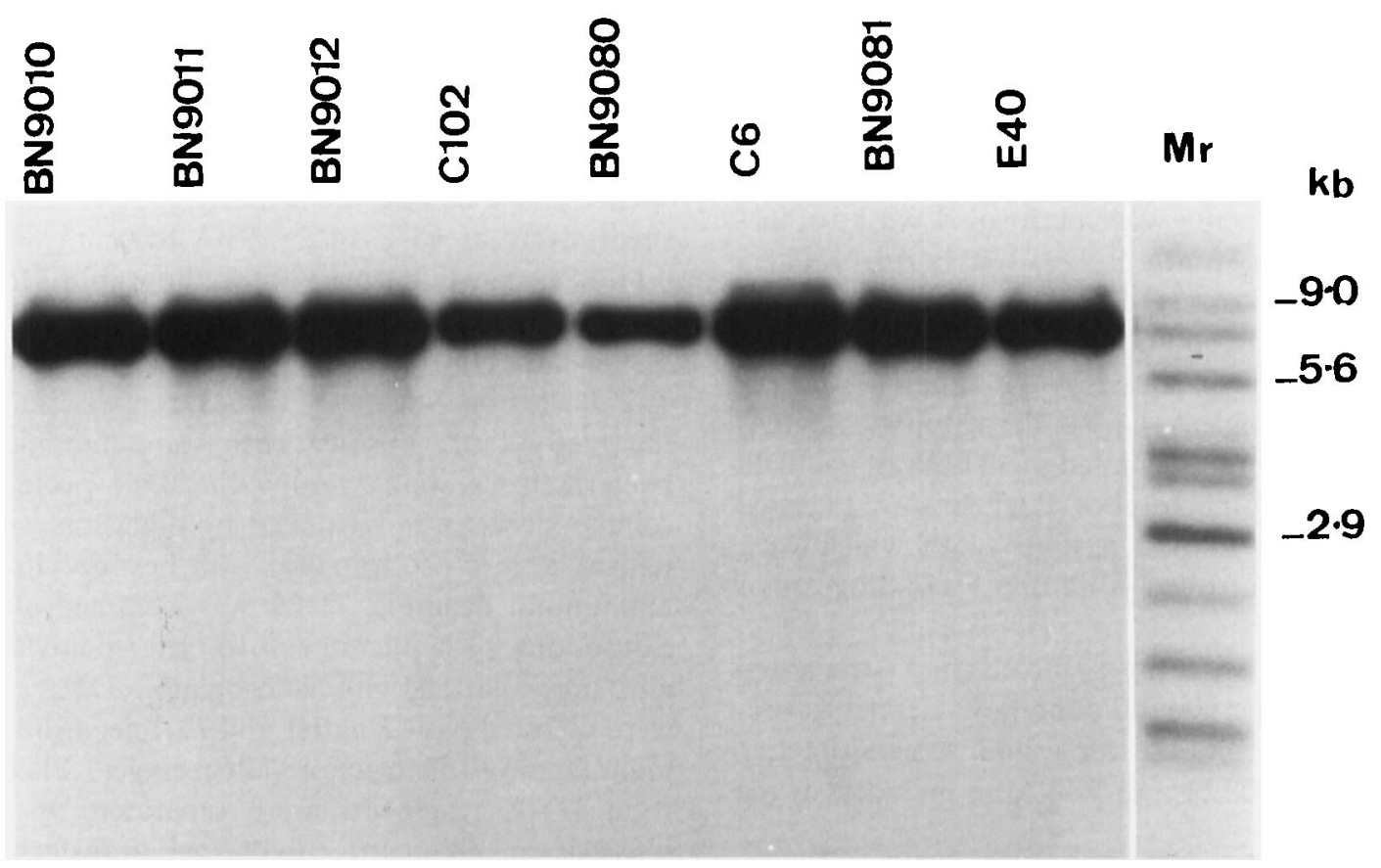

Fig. 2. Southern blot analysis. Chromosomal DNA of strains indicated at the top was digested with HindIII, separated by gel electrophoresis, transferred to a nylon membrane and hybridised with the ${ }^{32} \mathrm{P}$-radiolabelled $e a e A$ probe. Raoul ${ }^{\circledR}$ was used as mol. wt marker after hybridisation with ${ }^{32}$ P-radiolabelled pUC18 (Appligene, Illkirch, France).

Results of the bacterial counts performed after inoculation showed that rabbits excreted these strains rapidly at a concentration of $10^{8}-10^{9} \mathrm{cfu} / \mathrm{g}$ of faeces. Strain B10 was confirmed as highly pathogenic by the same criteria, as already described. ${ }^{2}$

No diarrhoea and no mortality were observed after inoculation with strains BN9080 or BN9081. The mean daily weight gain of the rabbits was approxi- mately $30 \mathrm{~g}$. The bacterial counts were $c .10^{5} \mathrm{cfu} / \mathrm{g}$ of faeces. As expected, ${ }^{2,17}$ strains C6, C124 and E40 were non-pathogenic in our experimental conditions.

\section{Colony and Southern hybridisation}

The 55 rhamnose-negative $\mathrm{O} 103, \mathrm{O} 26$ or rough strains hybridised with the eae $A$ probe. The eae $A$ 
sequence was also detected in six rhamnose-positive strains. Three of them belonged to serogroup $\mathrm{O} 128$ and three were of serogroup O132 (fig. 1). Total DNA of these eaeA positive strains was analysed further by Southern blot hybridisation for homology with the eae $A$ probe. The probe hybridised with fragments of similar mol. wt in all these strains: an 8-kb fragment generated by digestion with HindIII (fig. 2) and a 6-kb PstI-generated fragment (data not shown). The eaeA sequence was never detected on plasmids in any of these strains.

The 10 other rhamnose-positive strains belonging to serogroups $\mathrm{O} 2, \mathrm{O} 4, \mathrm{O} 15, \mathrm{O} 85, \mathrm{O} 102$ and $\mathrm{O} 103$ did not hybridise with the eaeA probe.

None of the 71 strains were observed to hybridise with the EAF, SLTI, SLTII, CVD419, F1845 and EAggEC probes.

\section{Discussion}

The results of animal experiments in this study were in good agreement with those previously obtained by Milon et al. ${ }^{2,17}$ Four strains were used to allow a comparison between these independent experiments. These strains exhibited non-variable and reproducible results and confirmed the validity of such experimental work. The 10 rhamnose-negative 0103 strains tested in this study were highly pathogenic for rabbits. From these results and those mentioned above, it appears that there is a good correlation between the inability to ferment rhamnose and the pathogenicity of the $\mathrm{O} 103$ strains isolated in France. In France, the strains isolated most frequently in cases of diarrhoea in weaned rabbits belong to serogroup $\mathrm{O} 103$ and are unable to ferment rhamnose. Until now, only a few O103 strains able to ferment rhamnose have been detected.

The two strains BN9080 and BN9081, belonging to serogroups O128 and O132, respectively, were nonpathogenic. Similar results were obtained with strains C6 and E40, belonging to the same serogroups, as already described. ${ }^{2,17}$

A total of 71 E. coli strains isolated in France from weaned diarrhoeic rabbits were studied with different DNA probes specific for EPEC, EHEC, DAEC and EAggEC of human origin. Positive results were observed only with the eaeA probe for all rhamnose-

\section{References}

1. Peeters JE, Geeroms R, Orskov F. Biotype, serotype, and pathogenicity of attaching and effacing enteropathogenic Escherichia coli strains isolated from diarrheic commercial rabbits. Infect Immun 1988; 56: 1442-1448.

2. Camguilhem R, Milon A. Biotypes and $O$ serogroups of Escherichia coli involved in intestinal infections of weaned rabbits: clues to diagnosis of pathogenic strains. $J$ Clin Microbiol 1989; 27: 743-747.

3. Cantey JR, Blake RK. Diarrhea due to Escherichia coli in the rabbit: a novel mechanism. J Infect Dis 1977 ; 135: 454-462

4. Milon A, Esslinger J, Camguilhem R. Adhesion of Escherichia negative and some rhamnose-positive rabbit strains. All these eaeA positive strains showed chromosomal hybridisation without noticeable restriction length polymorphisms in the sequences.

Sequences homologous to the eae $A$ gene were found in all the rhamnose-negative highly pathogenic strains. Therefore, the eaeA gene was not limited to the RDEC-1 strain $^{8}$ but occurred in other rabbit pathogenic strains of different origins belonging to various serogroups.

The eae $A$ probe also hybridised with the 0128 and O132 strains which were non-pathogenic under experimental conditions. Thus, the presence of the eae $A$ sequences in the rabbit $E$. coli strains was not strictly correlated with the full expression of pathogenicity in animal experiments. To our knowledge, this is the first report of the presence of the eae $A$ sequences in nonpathogenic strains.

The expression of the A/E factors in the EPEC strains of human origin is positively regulated by the EAF plasmid. ${ }^{12}$ In the EHEC and RDEC-1 strains lacking this plasmid, other non-homologous plasmids encoding fimbriae could have a similar function. ${ }^{9}$ At the present time, the role of the initial attachment in the development of $\mathrm{A} / \mathrm{E}$ lesions is not clearly defined. The highly pathogenic O103 strains and the nonpathogenic 0128 strains showed the same characteristics of adhesion to 6-week-old rabbit intestinal villi and HeLa cells, with a diffuse pattern. These properties were associated with the presence of a $32-\mathrm{kDa}$ adhesin in the $\mathrm{O} 103$ and $\mathrm{O} 128$ strains. ${ }^{4}$ The non-pathogenic $\mathrm{O} 132$ strains also exhibited a diffuse adherence pattern to HeLa cells. ${ }^{4}$ Thus, the difference of expression of pathogenicity in these eaeA-positive strains was not due to an alteration in their abilities to adhere in vitro.

This preliminary study has provided the basis for future research which could determine the conditions of expression of the eaeA gene in highly pathogenic rabbit $E$. coli strains and the involvement of the gene product in the expression of pathogenicity. Understanding of the significance of such sequences in nonpathogenic strains is also necessary.

We thank A. Milon for providing several rabbit E. coli strains, J. B. Kaper and S. S. Bilge for the gift of their reference probes and of the corresponding positive strains, P. J. Sansonetti for the other probes and Ms C. Rich for her help in testing the EAggEC probe. This work was supported in part by a grant from the Région Centre, France. S.M.L. is the recipient of a 'Région Centre/INRA' fellowship.

coli strains isolated from diarrheic weaned rabbits to intestinal villi and Hela cells. Infect Immun 1990; 58: 2690-2695.

5. Licois D, Reynaud A, Federighi M, Gaillard-Martinie B, Guillot JF, Joly B. Scanning and transmission electron microscopic study of adherence of Escherichia coli $\mathrm{O} 103$ enteropathogenic and/or enterohemorrhagic strain GV in enteric infection in rabbits. Infect Immun 1991; 59: 3796-3800.

6. Moon HW, Whipp SC, Argenzio RA, Levine MM, Giannella RA. Attaching and effacing activities of rabbit and human enteropathogenic Escherichia coli in pig and rabbit intestines. Infect Immun 1983; 41: 1340-1351. 
7. Francis DH, Collins JE, Duimstra JR. Infection of gnotobiotic pigs with an Escherichia coli $\mathrm{O} 157: \mathrm{H} 7$ strain associated with an outbreak of hemorrhagic colitis. Infect Immun 1986; 51: 953-956.

8. Jerse AE, Yu J, Tall BD, Kaper JB. A genetic locus of enteropathogenic Escherichia coli necessary for the production of attaching and effacing lesions on tissue culture cells. Proc Natl Acad Sci USA 1990; 87: 7839-7843.

9. Donnenberg MS, Kaper JB. Enteropathogenic Escherichia coli. Infect Immun 1992; 60: 3953-3961.

10. Jerse AE, Kaper JB. The eae gene of enteropathogenic Escherichia coli encodes a 94-kilodalton membrane protein, the expression of which is influenced by the EAF plasmid. Infect Immun 1991 ; 59: 4302-4309.

11. Nataro JP, Baldini MM, Kaper JB, Black RE, Bravo N, Levine MM. Detection of an adherence factor of enteropathogenic Escherichia coli with a DNA probe. J Infect Dis 1985; 152: $560-565$.

12. Jerse AE, Gicquelais KG, Kaper JB. Plasmid and chromosomal elements involved in the pathogenesis of attaching and effacing Escherichia coli. Infect Immun 1991; 59: 3869-3875.

13. Newland JW, Neill RJ. DNA probes for Shiga-like toxins I and II and for toxin-converting bacteriophages. $J$ Clin Microbiol 1988; 26: 1292-1297.
14. Levine MM, Xu J, Kaper JB et al. A DNA probe to identify enterohemorrhagic Escherichia coli of 0157: $\mathrm{H} 7$ and other serotypes that cause hemorrhagic colitis and hemolytic uremic syndrome. J Infect Dis 1987; 156: 175-182.

15. Bilge SS, Clausen CR, Lau W, Moseley SL. Molecular characterization of a fimbrial adhesin, F1845, mediating diffuse adherence of diarrhea-associated Escherichia coli to Hep-2 cells. $J$ Bacteriol 1989; 171: 4281-4289.

16. Baudry B, Savarino SJ, Vial P, Kaper JB, Levine MM. A sensitive and specific DNA probe to identify enteroaggregative Escherichia coli, a recently discovered diarrheal pathogen. J Infect Dis 1990; 161 : 1249-1251.

17. Milon A, Esslinger J, Camguilhem R. Oral vaccination of weaned rabbits against enteropathogenic Escherichia colilike E. coli $\mathrm{O} 103$ infection: use of heterologous strains harboring lipopolysaccharide or adhesin of pathogenic strains. Infect Immun 1992; 60: 2702-2709.

18. Finkelstein M, Rownd RH. A rapid method for extracting DNA from agarose gels. Plasmid 1978; 1: 557-562.

19. Takahashi S, Nagano Y. Rapid procedure for isolation of plasmid DNA and application to epidemiological analysis. $J$ Clin Microbiol 1984; 20: 608-613.

20. Wilson K. Preparation of genomic DNA. In: Ausubel FM, Brent R, Kingston RE et al. (eds) Current protocols in molecular biology, vol 1. New York. 1987: 2.4.1.-2.4.2. 